\title{
The Use of "Fermeherbafit" (Mixed Herbs) in Broiler Chicken Feed on Performance and Cholesterol Profile
}

\author{
Bambang Hartoyo*, Ning Iriyanti and Efka Aris Rimbawanto \\ Animal Science Faculty, Jenderal Soedirman University, Purwokerto \\ *Corresponding author email: ningiriyanti@gmail.com
}

\begin{abstract}
This research was aimed to imporve of broiler chiken performance and reduce the blood, meat and liver cholesterol levels. This research used 100 female broilers MB 200 Platinum DOC which were reared for 5 weeks at battery-postal cages. The treatments were $R_{0}=$ control/ $0 \%$ fermeherbafit; $R_{1}=$ used $2 \%$ fermeherbafit; $R_{2}=$ used $4 \%$ fermeherbafit; $R_{3}=$ used $6 \%$ fermeherbafit. The experimental design was carried out using a complete randomized design. Data were analyzed by analysis of variance (ANOVA). The results showed that the use fermeherbafit did not showed any significant differences $(P>0.05)$ in feed consumption, absolute growth, relative growth and carcas percentage. However, it showed significant differences $(P<0.05)$ in blood and breast meat cholesterols. The average for Performance (feed consumption by $3268.775 \pm 293.421$ $\mathrm{g} /$ bird; absolute growth by $1684.92 \pm 126.12$; relative growth by $0.3682 \pm 0.0019$; carcas percentage by $74.61 \pm$ $1.12 \%$ ). Blood cholesterol $89.20 \pm 12.76 \mathrm{mg} / \mathrm{dl}\left(R_{3}\right)$ up to $111.80 \pm 17.02 \mathrm{mg} / \mathrm{dl}\left(R_{0}\right) ;$ Breast meat cholesterol $150.03+11.64 \mathrm{mg} / \mathrm{g}\left(R_{3}\right)$ up to $174.88+8.53 \mathrm{mg} / \mathrm{g}\left(R_{0}\right)$; Leg meat cholesterol $173.00+7.21\left(R_{1}\right)$ up to $152.15 \pm 17.83 \mathrm{mg} / \mathrm{g}\left(R_{3}\right) ;$ Liver cholesterol $83.37 \pm 31.01 \mathrm{mg} / \mathrm{g}\left(R_{0}\right)$ up to $102.75 \pm 1.68 \mathrm{mg} / \mathrm{g}\left(R_{3}\right)$. Conclusion of this research was that the Fermeherbafit could be used in broiler feed up to $6 \%$ which could reduce blood and breast meat cholesterols.
\end{abstract}

Keywords: performance, cholesterol, fermeherbafit

Abstrak. Penelitian ini bertujuan untuk meningkatkan performen ayam dan menurunkan level kolesterol darah, daging dan hati.Penelitian menggunakan 100 DOC ayam broiler betina MB 200 Platinum yang dipelihara selama 5 minggu pada kandang battery-postal. Perlakuan berupa $R_{0}$ : control/ $0 \%$ fermeherbafit, $R_{1}$ : menggunakan $2 \%$ fermeherbafit, $R_{2}$ : menggunakan $4 \%$ fermeherbafit, $R_{3}$ : menggunakan $6 \%$ fermeherbafit. Desain eksperimental yang digunakan adalah rancangan acak lengkap. Data dianalisis dengan menggunakan analisis variansi (ANOVA). Hasil penelitian menunjukkan bahwa penggunaan fermeherbafit tidak berbeda nyata $(P>0.05)$ pada konsumsi pakan, pertumbuhan absolut, pertumbuhan relatif, dan persentase karkas. Namun demikian, penelitian menunjukkan pengaruh yang nyata $(\mathrm{P}<0.05)$ pada kolesterol darah dan daging dada. Rata-rata pertumbuhan (konsumsi pakan yaitu $3268,775 \pm 293,421$ g/ekor; pertumbuhan absolut yaitu $1684,92 \pm 126,12 \mathrm{~g}$; pertumbuhan relative yaitu $0.3682 \pm 0.0019 \mathrm{~g}$; persentase karkas yaitu $74.61 \pm 1.12 \%$ ). Kolesterol darah $89,20 \pm 12,76 \mathrm{mg} / \mathrm{dl}\left(\mathrm{R}_{3}\right)$ hingga $111,80 \pm 17,02 \mathrm{mg} / \mathrm{dl}\left(\mathrm{R}_{0}\right) ;$ kolesterol daging dada 150,03 $\pm 11,64$ $\mathrm{mg} / \mathrm{g}\left(R_{3}\right)$ hingga $174,88 \pm 8,53 \mathrm{mg} / \mathrm{g}\left(R_{0}\right) ;$ kolesterol daging paha $173,00 \pm 7,21\left(R_{1}\right)$ hingga $152,15 \pm 17,83 \mathrm{mg} / \mathrm{g}$ $\left(R_{3}\right)$; kolesterol hati $83,37 \pm 31,01 \mathrm{mg} / \mathrm{g}\left(\mathrm{R}_{0}\right)$ hingga $102,75 \pm 1,68 \mathrm{mg} / \mathrm{g}\left(\mathrm{R}_{3}\right)$. Kesimpulan penelitian didapatkan bahwa fermeherbafit dapat digunakan pada pakan broiler hingga $6 \%$ yang dapat menurunkan kolesterol darah dan daging dada.

Kata kunci: performen, kolesterol, fermeherbafit

\section{Introduction}

Chicken is a source of protein to meet the needs of nutrients for humans. The price of chicken is cheaper than the price of beef and mutton. Therefore, the demand will continue to increase (Ponte et al., 2004; Grashorn, 2007). Chicken meat industry is required to produce a low-fat meat because due to health reason. Therefore, broiler feed industry is required to develop additional feed to suppress the amount of fat content in broiler chicken carcass but do not reduce the efficiency of feed utilization and weight of broilers (Matsurra, 2001; Chowdhury et al., 2002).

Feeding chicken with herbs is aimed to improve animal health and stamina, growth stimulator, feed efficiency improvement, and the most important is reducing fat and cholesterol. Herbs which are usually used for chicken including Morinda citrifolia L. fruit, 
Andrographis paniculata (Burm.f.) Wall. ex. Nees leaves, Zingiber officinale L. tuber, Curcuma domestica Valeton. tuber, Languas galangal Stuntz. tuber, Curcuma xanthorrhiza Roxb. tuber, Piper betle L. leaves, Phaleria macrocarpa Boer., Kaempferia galanga L. tuber, Allium sativum L. bulb etc. Herbs can be used as single or mixed preparations and served through drinking water and or feed (Shahid and Bhanger, 2006; Karadi et al., 2006; Sharma et al., 2013).

Mixed herbs would be more beneficial when they are previously fermented. Fermentation could reduce the potential plant toxicant present in the product and improve the feed digestibility and nutritive value (Chen et al., 2009; Chiang et al., 2010) such as available vitamins and minerals for the animals. Fermentation could proceed naturally or manually by administering with lactic acid bacteria, cellulolytic and other microorganisms which are recognized as GRAS. The result of fermentation process would be amino acids, certain vitamins and minerals and alive microorganisms which benefit further metabolisms and improve the animal wellbeing.

Fat and cholesterol has became main concern for human health. Thus, effort have been done to control fat and cholesterol start from food material such as chicken meat. One alternative to tackling the problem of fat and cholesterol in broiler meat is the use of herbs in the feed (Chowdhury et al., 2002).

Each herb has active compounds which can reduce the levels of fat and cholesterol in meat. Curcumin and essential oils contained in turmeric and ginger. Active compounds contained in garlic is allicin which affects on the decrease in triglycerides in chickens. Vitamin C is found in moringa leaves contain carnitine which is capable to reduce level of fat and cholesterol of broiler meat. Fiber contained in morinda fruit (noni) is able to absorb excess water which causes the excess secretion of bile salts (Konjufca et al., 1997; Maheswari et al., 2006; Nazari et al., 2008; Bukar et al., 2010).

The use of giving herbs in feed intended to improve consumption, digestibility as well as endurance and reduce stress levels in broiler chickens. Herbal mixture which can be given is noni fruit (Morinda citrifolia), garlic (Allium sativum ), turmeric tuber (Curcuma domestica), curcuma tuber (Curcuma xanthorriza), and the leaves of moringa (Moringa oleifera) (Hernández et al., 2004; Amad et al., 2011; Sharma et al, 2013).

\section{Materials and Methods}

\section{Experimental livestock}

This research used 100 DOC (Day Old Chick) MB 202 platinum. They were reared for five weeks and randomly placed at bamboo battery cages, feed and water tanks were placed outside the front side of cage.

\section{Experimental feed}

The mixed herbs consisted of turmeric tuber, curcuma tuber, garlic bulb, morinda fruit and moringa leaves. Other materials were mollase and lactic acid bacteria (LAB).

All experimental diets were managed at isonutrient and isocaloric states, which were arranged to contain $21 \%$ feed protein and 3100 $\mathrm{cal} / \mathrm{kg}$ metabolic energy. The feed component included rice bran based, corn, fish meal, soybean meal, methionine and lysine were purchased. The feed also contained palm oil, $\mathrm{CaCO}_{3}$ and top mix (Table 1). The chemical composition of the feed was analyzed according to AOAC (2006). Feed and water were given ad libitum.

\section{Research procedures:}

\section{Preparation of herbs feed}

Herbs consisted of $25 \mathrm{~g}$ garlic, $50 \mathrm{~g}$ morinda fruit, $10 \mathrm{~g}$ moringa leaves, $100 \mathrm{~g}$ curcuma tuber, and $100 \mathrm{~g}$ turmeric tuber. All materials were chopped finely than added $2.5 \% \mathrm{w} / \mathrm{w}$ cane sugar molasses then inoculated with $L A B$ solution which contained $10^{6}-10^{8} \mathrm{cell} / \mathrm{ml}$ at 
$10 \% \mathrm{v} / \mathrm{w}$ concentration. Those mixed materials were incubated at $\mathrm{pH} 6.8$ in room temperature $\left(27-29^{\circ} \mathrm{C}\right)$ for $3 \times 24$ hours and was dried at $40 \circ \mathrm{C}$ for $2 \times 24$ hours afterward. The dried material then was grinded and measured for its nutritional content through proximate analysis.

\section{Experimental diet}

This research was conducted for five weeks using a Completely Randomized Design (Steel and Torrie, 1994). There were 100 DOC female broilers divided randomly in four groups of treatment that was $\mathrm{R}_{0}$ : Control/ $0 \%$ Fermeherbafit, $\mathrm{R}_{1}$ : used $2.0 \%$ Fermeherbafit; $R_{2}$ : use $4.0 \%$ Fermeherbafit; $R_{3}$ : use $6.0 \%$ Fermeherbafit respectively, and five repetitions. Each treatment group consists of five DOCs.

\section{Variables}

After five weeks observation, blood samples were taken from vessels under the wings (axillary vein). Three $\mathrm{ml}$ of blood samples were filled into tubes containing blood anticoagulants (EDTA/Ethylene Di-amine Tetra Acetic Acid).
Variables observed were performance and cholesterol profile: blood cholesterol, meat cholesterol (breast and leg), and liver cholesterol.

\section{Cholesterol Profile}

Blood cholesterol was determined by enzymatic activity of cholesterol oxidase paraamino phenazone (CHODPAP). Triglyceride was determined using enzymatic colorimetric method (DiaSys,Germany).

Meat and liver cholesterols were determined by comparing the result of sample absorbance with spectrophotometer at $680 \mathrm{~nm}$ with standard curve according to Lieberman and Burchard (Tranggono and Setiaji, 1989).

Statistical analyses: Data were analyzed using Nested ANOVA Completely Randomized Design (CRD). Any significant differences found between treatments, was then followed by the Honestly Significant Differences test (Steel and Torrie, 1994).

Table 1. Composition of Feed

\begin{tabular}{|c|c|c|c|c|}
\hline \multirow[t]{2}{*}{ Feedstuffs } & $\mathrm{R}_{0}$ & $\mathrm{R}_{1}$ & $\mathrm{R}_{2}$ & $\mathrm{R}_{3}$ \\
\hline & \multicolumn{4}{|c|}{$\%$} \\
\hline Corn & 50 & 50 & 50 & 50 \\
\hline Bran & 15 & 13 & 11 & 9 \\
\hline Soybean Meal & 20 & 20 & 20 & 20 \\
\hline Fish Meal & 10 & 10 & 10 & 10 \\
\hline Coconut Oil & 3.5 & 3.5 & 3.5 & 3.5 \\
\hline Premix & 0.5 & 0.5 & 0.5 & 0.5 \\
\hline $\mathrm{CaCO}_{3}$ & 0.5 & 0.5 & 0.5 & 0.5 \\
\hline Methionin & 0.25 & 0.25 & 0.25 & 0.25 \\
\hline Lysin & 0.25 & 0.25 & 0.25 & 0.25 \\
\hline Mixed herbs & 0 & 2 & 4 & 6 \\
\hline Total & 100 & 100 & 100 & 100 \\
\hline \multicolumn{5}{|l|}{ Nutrient contents } \\
\hline Crude Protein (\%) & 21.2 & 21.21 & 21.21 & 21.22 \\
\hline Metabolized energy (kcal/kg) & 3086 & 3086 & 3086 & 3086 \\
\hline Crude Fat (\%) & 4.05 & 4.032 & 4.013 & 3.995 \\
\hline Crude Fiber (\%) & 4.2 & 4.252 & 4.304 & 4.356 \\
\hline Са (\%)* & 0.967 & 0.967 & 0.967 & 0.967 \\
\hline $\mathrm{P}(\mathrm{av})(\%)^{*}$ & 0.5005 & 0.501 & 0.501 & 0.501 \\
\hline Lysin (\%)* & 0.7985 & 0.799 & 0.799 & 0.799 \\
\hline Methionin (\%)* & 0.545 & 0.545 & 0.545 & 0.545 \\
\hline
\end{tabular}




\section{Results and Discussion}

Proximat analysis of mixed herbs consists of $12.29 \%$ protein, $3.08 \%$ lipid, $13.6 \%$ raw fiber, $62.51 \%$ BETN, 17681.34 ppm Fe mineral, 55.02 ppm Se mineral and 2242.92 ppm Zn mineral.

\section{Broiler Performance}

The result of broiler performan showed in Table 2. Feed consumption is the amount of feed that can be eaten at any given time. Chicken feed consumption depends on several factors, namely the type of strain, liveliness, feed quality and quantity of feed andmanagement.

In addition, broilers tend to increase the amount of consumption of low-energy feed. The results showed that the average value of chicken feed consumption of broiler research ranged from $3213,912 \pm 235,531$ to $3309,378 \pm$ 291,616 gram (Table 2).

The result of variance analysis showed that broiler chicken with herbal supplementation had no significant effect $(P>0,05)$ to feed consumption. The average value of chicken feed consumption of broiler research is $3268.775 \pm$ 293.421 grams / head. This is in accordance with the NRC (1994) recommending that the broiler's metabolic energy requirement is 3200 $\mathrm{Kcal} / \mathrm{kg}$ with standard feed consumption of 3000 grams / tail during the 0-6 week growth.

Body weight growth is the result of enlargement of muscle tissues and other tissues formed by the increase of materials such as fats, carbohydrates, minerals, and water.
Growth can be seen in the increase in body weight obtained by weighing broiler chickens daily, weekly or according to a certain period of time. The results showed that the absolute growth rate of broiler chickens ranged between $1528.02 \pm 181.03$ to $1791.82 \pm 80.02$ grams / head, while the average relative growth of broiler chickens ranged from $0.3648 \pm 0.0044$ to $0.3702 \pm 0.0022$ grams / day. The result of variance analysis showed that herbal supplementation had significant effect $(P<0,05)$ on absolute growth and relative growth.

This is thought to be due to the herbal ingredients used during the study consisting of five kinds that overall can increase feed consumption, thus increasing the growth as well. In addition to influential feed intake, there are other factors such as strain, feed, livestock age, production status, temperature, system perkandangan, and disease control. These factors are influenced predominantly by the feed consumed by livestock.

The results showed that feeding treatment with $2 \%$ or $2 \%$ herb addition resulted in the highest absolute growth of $1791.82 \pm 80.02$ gram / head while the feeding treatment with $4 \%$ or $4 \%$ herbal addition resulted in the lowest growth of broiler chicken 1528, $02 \pm 181,03$ gram / tail. The relative growth of broiler chicken is the highest feeding treatment with $0 \%$ or $0 \%$ herb addition that is $0,3702 \pm 0,0022$ gram / day while the lowest relative growth is

Tabel 2. The Performance of broiler chikens with Mixed Herb

\begin{tabular}{|c|c|c|c|c|}
\hline Experimen & Feed Consumtion $(\mathrm{g})^{\mathrm{ns}}$ & Absolut of Growth $(\mathrm{g})^{*}$ & $\begin{array}{l}\text { Relatife of Growth } \\
(\mathrm{g} / \text { day })^{*}\end{array}$ & Carcas Presentage (\%) \\
\hline Ro & $3276.784 \pm 312.449$ & $1643.46 \pm 153.44$ & $0.3702 \pm 0.0022$ & $73.56 \pm 1.47$ \\
\hline $\mathrm{R}_{1}$ & $3309.378 \pm 291.616$ & $1791.82 \pm 80.02$ & $0.3696 \pm 0.0023$ & $73.55 \pm 1.48$ \\
\hline $\mathrm{R}_{2}$ & $3275.024 \pm 334.087$ & $1528.02 \pm 181.03$ & $0.3648 \pm 0.0044$ & $72.48 \pm 3.01$ \\
\hline $\mathrm{R}_{3}$ & $3213.912 \pm 235.531$ & $1776.38 \pm 89.99$ & $0.3682 \pm 0.0019$ & $74.61 \pm 1.12$ \\
\hline Rataan & $3268.775 \pm 293.421$ & $1684.92 \pm 126.12$ & $0.3682 \pm 0.0027$ & $73.55 \pm 1.77$ \\
\hline
\end{tabular}


treatment with $4 \%$ herb addition or R2 that is $0,3648 \pm 0,0044$ grams / day. The results showed that the feed treatment with the addition of herbs $4 \%$ or R2 has the value of growth of both absolute and relative the lowest compared with other treatments. This is allegedly caused by the consumption of broiler feed R2 treatment is relatively low because of growth is strongly influenced by feed consumption.

The percentage of carcass is calculated by dividing the carcass weight by the weight of life and multiplied by $100 \%$. The calculation of broiler chicken carcass percentage percentage based on research data gives average average carcass percentage yield equal to $73,551 \pm$ $1,77 \%$ with range $72,482 \pm 3,008 \%$ until 74,610 $\pm 1,115 \%$. The result of variance analysis showed that herbal supplementation in feed had no significant effect $(P>0,05)$ to broiler chicken carcass percentage. Treatment of herbal addition $(0 \%, 2 \%, 4 \%$ and $6 \%$ ) gave the same relative influence to broiler chicken carcass weight percentage. No effect caused by the nutrient content in the experimental ration is not much different. Soeparno (1994), states that the factors that determine the percentage of carcass is age, weight, fatty, and the contents of the digestive tract.

The percentage of carcass is determined by the size of the wasted body parts such as head, neck, legs, viscera, fur and blood. Judging from the essential oil content of temulawak and turmeric that can accelerate the emptying of the stomach then will cause hunger and stimulate the appetite later and ultimately affect the weight gain and affect the percentage of carcass. In accordance with the opinion of Saenab et al., (2006) which states that the provision of temulawak, turmeric and kencur contained in herbal medicine can increase appetite and increase the metabolism ability of the chicken body so that it can affect the growth of meat. Zumbrotun (2012) states that the provision of herbal medicine or medicinal plants are mixed in both feed and chicken water can be useful to increase chicken weight and increase appetite so that it can affect the increased percentage of carcass weight.

\section{Cholesterol Profile}

Blood, breast meat, leg meat and liver cholesterol profiles decreased following feeding with feed containing mixed herbs. Complete result was shown in Table 2.

The result indicated the differences were found in blood and breast meat cholesterols compared to control. Blood cholesterol content of broiler decreased $22.21 \%$ compared with average content of treatments were $89.20 \pm 12.76 \mathrm{mg} / \mathrm{dl}$ to $96.20 \pm 5.54 \mathrm{mg} / \mathrm{dl}$ and control was 111.80 to $17.02 \mathrm{mg} / \mathrm{dl}$. In addition, the reduction of breast meat cholesterol was $14.21 \%$ which average between $150.03 \pm 11.64$ $\mathrm{mg} / \mathrm{g}$ to $167.72 \pm 10.74 \mathrm{mg} / \mathrm{g}$, compared to control which was $174.88 \pm 8.53 \mathrm{mg} / \mathrm{g}$. Blood cholesterol content in this research was much lower than result from Murwani et al. (2011) which was 94.19 to $144.32 \mathrm{mg} / \mathrm{dl}$. In addition, Paryad and Mahmoudi (2008) reported the

Table 2. Average of blood, breast meat, leg meat and liver cholesterols of broiler

\begin{tabular}{lcccc}
\hline Treatment & $\begin{array}{c}\text { Blood cholesterol } \\
(\mathrm{mg} / \mathrm{dl})^{*}\end{array}$ & $\begin{array}{c}\text { Breast meat } \\
\text { cholesterol } \\
(\mathrm{mg} / \mathrm{g})^{* *}\end{array}$ & $\begin{array}{c}\text { Leg meat } \\
\text { cholesterol } \\
(\mathrm{mg} / \mathrm{g})^{\mathrm{ns}}\end{array}$ & $\begin{array}{c}\text { Liver cholesterol } \\
(\mathrm{mg} / \mathrm{g})^{\mathrm{ns}}\end{array}$ \\
\hline Control & $111.80 \pm 17.02^{\mathrm{a}}$ & $174.88 \pm 8.53^{\mathrm{a}}$ & $167.93 \pm 13.36$ & $102.75 \pm 1.68$ \\
Mixed herbs 2\% (w/w) & $96.20 \pm 5.54^{\mathrm{b}}$ & $167.72 \pm 10.74^{\mathrm{b}}$ & $173.00 \pm 7.21$ & $92.81 \pm 25.01$ \\
Mixed herbs 4\% (w/w) & $90.20 \pm 9.23^{\mathrm{b}}$ & $155.36 \pm 10.45^{\mathrm{ab}}$ & $161.09 \pm 6.29$ & $85.91 \pm 38.94$ \\
Mixed herbs 6\% (w/w) & $89.20 \pm 12.76^{\mathrm{b}}$ & $150.03 \pm 11.64^{\mathrm{c}}$ & $152.15 \pm 17.83$ & $83.37 \pm 31.01$ \\
\hline
\end{tabular}

Note $^{* *}=$ very significantly affected $(P<0.01) ; *=$ significantly affected $(P<0.05) ; n s=$ no significant. Different notation in the same column indicated significant different 
blood cholesterol of broiler was 138.11 to $151.55 \mathrm{mg} / \mathrm{dl}$, and 83.50 to $108.00 \mathrm{mg} / \mathrm{dl}$ in pullet (Bamidele and Adejumo, 2012).

Result of ANOVA indicated that the treatment significantly affected $(P<0.05)$ on the breast meat cholesterol and very significantly affected $(\mathrm{P}<0.01)$ on the blood cholesterol. However, the treatment did not affect on the leg and liver cholesterols.

Blood cholesterol of chicken fed with mixed herbs in their feed was lower than control, and its reduction was in line with the content of mixed herbs in feed (Table 2.). It indicated that mixed herbs consumption up to $6 \%$ could serve as lipid and cholesterol contents reducer. Mixed herbs was used as feed additive which has bioactive substances that inhibits cholesterol development in two ways, those are 1) inhibits the rate of 3-hydroxy-3methylglutaryle-Coenzyme A (HMG-CoA) reductase activity which is enzyme that inhibits lovasterol from feed lipid and metabolic lipid. As a results, the reduction in cholesterol development will occur, and 2) increase bile secretion which will bring cholesterol from intestine along with feces out from the body. The rest of cholesterol in tissues will be returned to liver and brought by HDL along with bile acid in intestine then will be released as excretes. Roos and Katan (2000) mentioned that increasing bile acid will increase the cholesterol excretion resulting the reduction of cholesterol content in tissue.

Mixed herbs used in this study were moringa leaves, morinda fruit, curcuma tuber, turmeric tuber and garlic bulb. Morinda fruit contains digestive enzymes, vitamins and antibacterial substances such as antraquinon, acubin and alizarin, as well as nutrient such as protein (9.02\%) and metabolic energy (3117 kcal $/ \mathrm{kg})$, xeronin and precursor xeronin. Proxeronin will be transformed to xeronin by proxeronase in the intestine, then absorbed by body cells to activate inactive proteins and control structure and shape of non-active cells. Scopoletin will bind serotonin which is a substance which usually cause narrowing the blood vessel and increasing blood pressure (Solomon, 1998). Scopoletin are found to have analgesic property and have an ability to control serotonin levels in the body and are responsible for most therapeutic activity of $M$. citrifolia (Wang and Su, 2001).

Cholesterol reduction in the blood will be followed by reduction of breast meat cholesterol as aggression line equation: $\mathrm{Y}=$ $0.8409 x-39.37$ and R2 $=0.8355$ (Graph. 1).

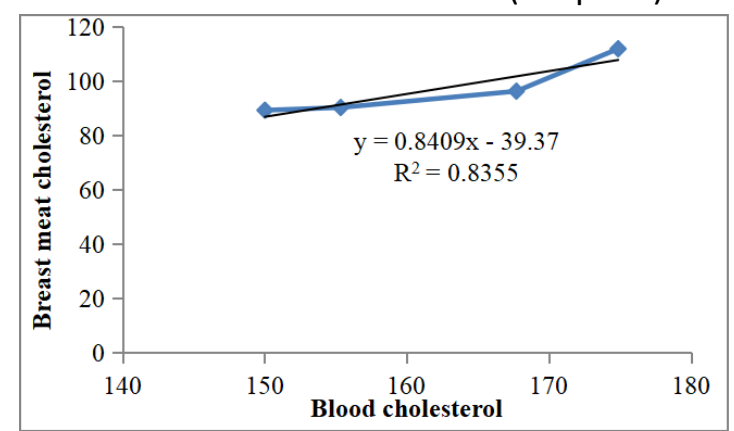

Figure 1. Interaction between blood cholesterol and breast meat cholesterol

Allium sativum L. bioactive compound is allicin (thiopropen sulfinic acid allyl ester) which is capable to reduce blood cholesterol. According to Prasad et al. (2012) and Yeh and Liu (2001), garlic was effective in lowering the total cholesterol through its effect on the plasma concentration of LDL cholesterol. Cholesterol of leg meat and liver did not show any significant differences $(P>0.05)$, even though based on the average of the analysis indicated reduction in cholesterol content. It could come from the fact that lipid metabolism in leg meat will produce fatty acids and glyceride which will be used as energy source. However, cholesterol of liver will be reenter into blood circulation along with HDL (High Density Lipoprotein). As mentioned by Meyer et al. (2003) that HDL will bring cholesterol from cells and tissues to the liver then recirculate to cells and tissues. 


\section{Conclusions}

The use of mixed herbs in broiler chicken's feed up to $6 \%$ could reduce the meat's cholesterol level. It can also be used as feed additive to maintain the stamina and health of the chicken without interfering the chicken's protein metabolism.

\section{References}

Amad, A.A., K. Männer, K.R. Wendler, K. Neumann and J. Zentek. 2011. Effects of a phytogenic feed additive on growth performance and ileal nutrient digestibility in broiler chickens. Poultry Science, $90: 2811-2816$.

AOAC. 2006. Official Methods of Analysis, 16th Ed., AOAC, Washington, DC.

Bamidele, O. and I.O. Adejumo. 2012. Effect of Garlic (Allium sativum L.) and Ginger (Zingiber officinale Roscoe) Mixtures on Performance Characteristics and Cholesterol Profile of Growing Pullets. International Journal of Poultry Science, 11 (3): 217-220.

Bukar, A., A. Uba and T.I. Oyeyi. 2010. Antimicrobial Profile of Moringa oleifera Lam. Extracts against Some Food-borne Microorganism. Bayero Journal of Pure and Applied Sciences, 3(1): $43-48$.

Chen, K.L., W.L. Kho, S.H. You, R.H. Yeh, S.W. Tang and C.W. Hsieh. 2009. Effects of Bacillus subtilis var. natto and Saccharomyces cerevisiae mixed fermented feed on the enhanced growth performance of broilers. Poultry Science, 88 (2): 309-315.

Chiang, G., W.Q. Lu, X.S. Piao, J.K. Hu, L.M. Gong and P.A. Thacker. 2010. Effects of feeding solid-state fermented rapeseed meal on performance, nutrient digestibility, intestinal ecology and intestinal morphology of broiler chickens. AsianAustralasian Journal of Animal Sciences, 23(2): 263-271.

Chowdhury, S.R., S.D. Chowdhury and T.K. Smith. 2002. Effects of Dietary Garlic on Cholesterol Metabolism in Laying Hens. Poultry Science 81:1856-1862.

Grashorn, M.A. 2007. Functionality of Poultry Meat. Journal of Applied Poultry Research, 16: 99-106.

Hernández, F., J. Madrid, V. García, J. Orengo and M.D. Megías. 2004. Influence of Two Plant Extracts on Broilers Performance, Digestibility and Digestive Organ Size1. Poultry Science, 83:169-174.

Karadi, R. V., N B. Gadge, K.R. Alagawadi and R.V. Savadi. 2006. Effect of Moringa oleifera Lam. root-wood on ethylene glycol induced urolithiasis in rats. Journal of Ethnopharmacology, 105 (1-2): 306-311.

Konjufca, V. H., G.M. Pesti and R.I. Bakalli. 1997. Modulation of Cholesterol Levels in Broiler Meat by Dietary Garlic and Copper. Poultry Science, 76:1264-1271.

Maheswari, R.K., A.K. Singh, J. Gaddipati, R C. Srimal. 2006. Multiple biological activities of curcumin: $A$ short review. Life Sciences, 78(18) : 2081-2087.

Matsurra, H. 2001. Saponins in garlic as modifiers of the risk of cardiovascular disease. Journal of Nutrition, 131:1000S-1005S.

Meyer, B.J., N.J. Mann, J.L. Lewis, G.C. Milligan, A.J. Sinclair and P.R. Howe. 2003. Dietary intakes and food sources of omega-6 and omega-3 polyunsaturated fatty acids. Lipids. 38: 391-398.

Murwani, R., A. Indriani, I. Yuliana, K. Wihardani, M.A. Wahyuningrum, N.R. Tawakal, Mulyono and E. Kusumanti. 2011. Blood biochemical indices and productivity of broilers on diet supplemented with mannan oligosacharide, baker yeast, or combined baker yeast and noni leaves extracts. International Journal of Poultry Science, 10 (12): 990-997.

Nazari, B., F. Nilforoushzadeh, G. Mozhgan, M. Nilforoushzadeh, M.R. and A. Bahonar. 2008. Comparison of the Effect of Different Levels of Garlic Powder on the Levels of Serum Cholesterol and Triglyceride of Two Strains Broiler Chicks (Arian and Ross). Qom University of Medical Sciences Journal, 2 (3): 33-37.

NRC. The National Research Council for Poultry. 1994. Ninth Revised Edition. National Academy Press. Washington, D.C.

Paryad, A. and M. Mahmoudi. 2008. Effect of different levels of supplemental yeast (Saccharomyces cerevisiae) on performance, blood constituents and carcass characteristics of broiler chicks. African Journal of Agricultural Research, Vol. 3(12): 835-842.

Ponte, P.I.P., I. Mendes, M. Quaresma, M.N.M. Aguiar, J.P.C. Lemos, L.M.A. Ferreira, M.A.C. Soares, C.M. Alfaia, J.A.M. Prates, and C.M.G.A. Fontes. 2004. Cholesterol Levels and Sensory Characteristics of Meat from Broilers Consuming Moderate to High Levels of Alfalfa. Poultry Science, 83: 810-814.

Prasad, R., M.K. Rose, M. Virmani, S.L. Garg and J.P. Puri. 2012. Lipid Profile of Chicken (Gallus domesticus) in Response to Dietary Supplementation of Garlic (Allium sativum). International Journal of Poultry Science, 8 (3): 270-276.

Roos, De N.M. and M.B. Katan. 2000. Effects of probiotic bacteria on diarrhea, lipid metabolism and carcinogenesis; a review of paper published 
between 1988 and 1998. American Journal of Clinical Nutrition, 71, 2, 405-411.

Saenab, A, B. Bakrie, T. Ramadhan dan Nasrullah. 2006. Pengaruh Pemberian Jamu Ayam Terhadap Kualitas Karkas Ayam Buras. Buletin ilmu Peternakan dan Perikanan. Vol 10 (2): 133-143.

Shahid, I. and Bhanger, M. I. 2006. Effect of Season and Production Location on Antioxidant Activity of Moringa oleifera Leaves Grown in Pakistan. Journal of Food Composition and Analysis, 19 (6-7): 544-551.

Sharma, N., P. Sharma, N.D. Jasuja and S.C. Joshima. 2013. Hypocholesterolemic and Antioxidant Potentials of Some Plants and Herbs: A Review. Research and Reviews. Journal of Zoological Sciences, 1(2): 26-42.

Shenatmoko, A.D., A. Kurniawan, G.C.V. Gumilar, A. Ratriyanto, R.A Indreswari dan R. Dewanti. 2013. Pengaruh Suplementasi Betain terhadap Beberapa Parameter Lipida dan Protein Darah pada Puyuh. Sains Peternakan, 11 (1): 14-18.
Solomon, N. 1998. Nature's Amazing Healer, Noni. Woodland Publishing, Pleasant Groove. http://www.noni-is-good-for-you.com/view. Asp.

Steel, G.D. and J.H. Torrie. 1994. Principle and procedures of statistics. $2^{\text {nd }}$ Ed. McGraw-Hill Book Co., Inc., New York.

Tranggono dan B. Setiaji. 1989. Kimia Lipida. PAU Pangan dan Gizi Universitas Gadjah Mada, Yogyakarta.

Wang, M.Y. and C. Su. 2001. Cancer preventive effect of Morinda citrifolia (Noni). Annals of the New York Academy of Sciences, 952: 161-168

Yeh, Y.Y. and L. Liu, 2001. Cholesterol lowering effect of garlic extracts and organosulphur compounds: Human and animal studies. Journal of Nutrition, 131: 989S-993S.

Zumbrotun, 2012. Jamu Sebagai Feed Additive Dan Feed Suplement Untuk Meningkatkan Efisiensi Dan Kesehatan Broiler. http://vedca.siap.web.id/ Diakses pada Tanggal 15 Juni 2018. 